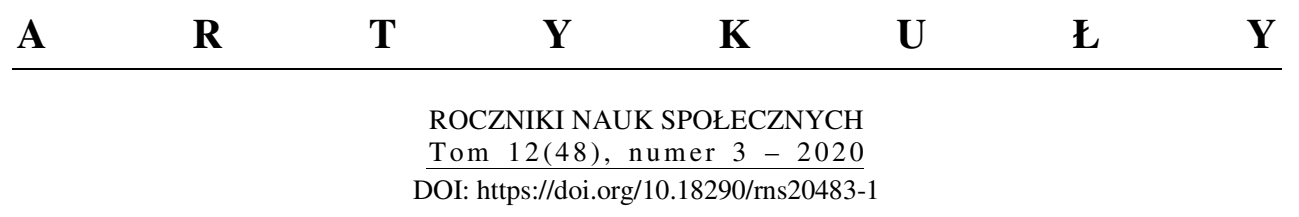

\title{
CZYNNOŚCI LUDZKIE JAKO OBIEKTYWNY WYMIAR BADAŃ NAUK HUMANISTYCZNYCH. ANALIZA PORÓWNAWCZA KONCEPCJI KAZIMIERZA TWARDOWSKIEGO I FLORIANA ZNANIECKIEGO
}

Celem artykułu jest analiza jednego z mniej obecnych we współczesnych naukach humanistycznych i społecznych polskiego wyrażenia „czynność ludzka”, stosowanego do opisu zachowań człowieka zarówno w wymiarze indywidualnym, jak i społecznym. Tekst ma charakter analityczno-syntetyczny z pogranicza historii idei i metodologii. Analizie poddane zostaną w nim koncepcje czynności ludzkich dwóch wielkich polskich uczonych - filozofa i logika Kazimierza Twardowskiego oraz filozofa i socjologa Floriana Znanieckiego. Prezentują oni sposoby konceptualizacji czynności ludzkich, które uzupełniają się logicznie i wyznaczają różne obszary opisu twórczych zachowań człowieka. Pozwala to uzyskać pełniejsze rozumienie rzeczywistości tworzonej przez człowieka, w tym rzeczywistości kulturowo-społecznej. Postaram się odpowiedzieć na następujące pytanie problemowe: Jakie podejście badawcze w naukach humanistycznych wynika z koncepcji czynności ludzkich Twardowskiego i Znanieckiego?

\section{NATURA CZYNNOŚCI LUDZKICH}

Uczeni, których koncepcje zostaną porównane, stali z pozoru na antypodach wrażliwości naukowej. Starszy z tej dwójki, Kazimierz Twardowski, jest w historii

Dr hab. ARKADIUSZ JABŁOŃSKI, prof. KUL - Instytut Socjologii, Katolicki Uniwersytet Lubelski Jana Pawła II; adres do korespondencji: Al. Racławickie 14, 20-950 Lublin; e-mail: arkadiusz.jablonski@kul.pl; ORCID: https://orcid.org/0000-0001-8081-2217. 
filozofii wiązany z empiryzmem logicznym ${ }^{1}$, zwanym też neopozytywizmem, a młodszy o 20 lat Florian Znaniecki może być uważany za przedstawiciela „przełomu antypozytywistycznego” w socjologii ${ }^{2}$. Elżbieta Hałas wskazuje co prawda, że: „Znaniecki podjął za Bergsonem i Jamesem, a także za polskim wybitnym wczesnym fenomenologiem Kazimierzem Twardowskim analizę doświadczenia »tu i teraz «", to jednak takie zestawienie rzadkie jest w polskiej literaturze przedmiotu. Obu myślicieli łączy oryginalność podejścia do podejmowanych problemów. Nie byli kontynuatorami któregoś z programów zaliczanych do prezentowanych przez siebie nurtów, ale byli twórcami nadającymi im własne oblicze intelektualne. Dlatego mimo odmiennych wrażliwości naukowych i różnych ram filozoficznego odniesienia własnych dociekań stworzyli narzędzia analityczne, przydatne naukom humanistycznym i społecznym do wyjaśniania rzeczywistości poprzez pryzmat ludzkich czynności. Pojęcie czynności zostało w dużej mierze wyparte przez określenie działania, a tym samym pozbawione należnego jej miejsca w naukach humanistycznych. Nie chodzi jednak tylko o zastąpienie jednego słowa przez jego współczesny odpwiednik semantyczny, ale zagubienie inspirujących koncepcji wypracowanych przez polskich autorów.

Koncepcja czynności lwowskiego filozofa, po jego odejściu od psychologizmu ${ }^{4}$, wychodzi od rozważań semiotycznych i rozpatrzenia pary takich wyrazów, jak: chodzić-chód, mówić-mowa, myśleć-myśl, błądzić-błąd itd. Po lewej stronie są wyrazy momentu czynnościowego (czasownik), a po drugiej momentu zjawiskowego (rzeczownik). Zgodnie z tym relacja czasownika do odpowiadającego mu jako dopełnienie wewnętrzne rzeczownika ,[...] wyraża stosunek jakiejś czynności do tego, co dzięki, wskutek tej czynności, przez tę czynność powstaje [...]. To, co dzięki, wskutek jakiejś czynności, czyli przez tę czynność powstaje, nazwać można w y t w o r e m tej czynności”" Wytwory można różnicować ze względu na to, czy powstają poprzez czynność odtwarzającą (np. z pamięci) czy też dzięki czynności twórczej z fantazji, zatem twórczości oryginalnej. Twardowski dokonuje też zasadniczego odróżnienia czynności i wytworów fizycznych

\footnotetext{
${ }^{1}$ J. WolEŃSKI, Twardowski Kazimierz, w: Encyklopedia filozofii polskiej, t. 2, Lublin: Polskie Towarzystwo Tomasza z Akwinu 2011.

${ }^{2}$ Ł.M. DOMINIAK, O źródtach kreatywności Floriana Znanieckiego, ,Filo-Sofia” 2017, nr 39, s. 184.

${ }^{3}$ E. HAŁAS, Znaczenia $i$ wartości społeczne. O socjologii Floriana Znanieckiego, Lublin: Redakcja Wydawnictw KUL 1991, s. 12.

${ }^{4}$ Zob. E. PaczKowska-Łagowska, Psychika i poznanie. Epistemologia Kazimierza Twardowskiego, Warszawa: Wydawnictwo Naukowe PWN 1980.

${ }_{5}^{5}$ K. TwARDOWSKI, O czynnościach i wytworach. Kilka uwag z pogranicza psychologii, gramatyki i logiki, Kraków: Drukarnia Uniwersytetu Jagiellońskiego 1911, s. 6.
} 
(chodzić-chód, biegać-bieg, skakać-skok) oraz czynności i wytworów psychicznych (myśleć-myśl, sądzić-sąd, zamierzać-zamiar).

Czynności interesują go jednak jako konieczny element rozpatrywania wzajemnych stosunków między wytworami ${ }^{6}$. Dlatego szczególne znaczenie nadaje czynnościom, które nazywa psychofizycznymi, czyli takimi, gdy czynności fizycznej towarzyszy czynność psychiczna, wywierająca jakiś wpływ na przebieg czynności fizycznej, a tym samym na powstający dzięki niej wytwór: mówić-mowa, kłamać-kłamstwo ${ }^{7}$. Wiele wytworów może być jednak traktowane w zależności od znaczenia określającego je rzeczownika jako fizyczne (np. ujęcie - czyli złapanie kogoś), psychiczne (np. ujęcie - jako sposób myślenia) lub psychofizyczne (np. ujęcie - jako konkretny sposób przedstawienia czegoś w tekście, na obrazie itp.). Ta wielorakość wytworów oznaczanych jednym terminem jest według Twardowskiego dodatkowo komplikowana faktem, że pewne sposoby użycia rzeczowników wskazują zarówno na wytwór, jak i samą czynność. Istotniejszy jest jednak fakt, że o wytworach możemy orzekać w taki sposób, w jaki nie możemy orzekać o czynnościach ${ }^{8}$. Twardowski wskazuje na związek między zamiarem użycia wytworu psychofizycznego jako znaku a treścią tego wytworu. Treść ta nie jest nigdy wyrazem konkretnego zamiaru twórcy, ale czymś „,do czego dochodzimy drogą abstrahowania, dokonanego na konkretnych wytworach"”. Analogicznie do wytworów w czynnościach psychofizycznych wyraża się odpowiednia czynność psychiczna.

Twardowski zwraca też uwagę na taki rodzaj czynności, które ujmowane być mogą jako środki do dokonywania tych czynności, których ,,[..] wytwory znajdują następnie pośredni wyraz w wytworze psychofizycznym. Te czynności i wytwory pomocnicze są tym, co nazywa się w ścisłym znaczeniu tego słowa

${ }^{6}$ J. BOBRYK, Twardowski. Teoria działania, Warszawa: Prószyński i S-ka 2001, s. 45 n.; P. BRYKCZYŃSKI, Kazimierza Twardowskiego koncepcja wytworów czynności, „Filozofia Nauki” 2005, nr 2 (50), s. 27-68.

${ }^{7}$ Tamże, s. 6-7.

8 „Fakt ten polega na tym, że o wytworach orzekamy niejedno, czego nie powiadamy o dotyczących czynnościach. Mówimy np. o określaniu pojęć, przy czym nie chodzi o określanie pojmowania; pewne pytania nazywamy niezrozumiałymi, nie chcąc tym samym twierdzić, jakoby stawianie pytań było czynnością niezrozumiałą; charakteryzujemy niekiedy jakieś zadanie jako nierozwiązywalne, co się oczywiście nie może tyczyć czynności zadawania; zarzucamy komuś, że przeoczył błąd, co wcale nie ma znaczyć, że przeoczył czynność błądzenia; mówimy o niespełnionych marzeniach, o postanowieniach, które nie zostały wprowadzone w czyn, a nie wyrażamy się w ten sposób o czynności marzenia albo o czynności postanawiania; mówimy o »złotych myślach« znakomitego pisarza, ale nie nazwiemy złotym jego myślenia. Widocznie więc chodzi nam o coś innego, gdy mówimy o wytworach, a co innego, gdy mówimy o dotyczących czynnościach, wobec czego rozróżnienie czynności i wytworów jest rzeczą zupełnie uzasadnioną". Tamże, s. 13-14.

${ }^{9}$ Tamże, s. 26. 
»techniką «"10. W tym sensie można mówić o zjawisku trwania czynności w wytworach, które jest efektem przeobrażenia, któremu uległ materiał czynności. Specyfika wytworów nietrwałych polega na tym, że nie istnieją w znaczeniu aktualnym niezależnie od czynności, lecz w połączeniu z nimi. Wytwory nietrwałe mogą być zarówno psychiczne (myśl), jak i fizyczne (krzyk). Nietrwałości takich wytworów nie powinno się - zdaniem Twardowskiego - podważać, mówiąc przykładowo o myślach jakiegoś myśliciela, że przetrwały go i trwają na wieki. Wtedy chodzi bowiem o powtarzanie przez pokolenia pewnych czynności i wytworów podobnych do tych, które zachodziły w owym myślicielu, a nie o niezależne od czynności trwałe, aktualne istnienie tych myśli.

Jeżeli Twardowski interesował się czynnościami, wychodząc od analizy części mowy języka polskiego, to Znaniecki widział czynności w kontekście sądów wyrażanych przez podmioty ludzkie. W ujęciu tym czynności ludzkie są tworzącymi ład kulturowy aktywnościami kierowanymi przez sądy wartościujące i normatywne ${ }^{11}$. Liczba i rozmaitość czynności zależy w tym ujęciu od ich treści i znaczeń, które nadają przedmiotom. Dokonywana w ten sposób racjonalizacja rzeczywistości jest zdaniem polskiego socjologa spontaniczna lub zamierzona. Znaniecki, nazywając jakąs czynność działalnością zamierzoną, wskazuje, że dokonuje ona wśród przedmiotów, do których się odnosi, „wprowadza do wybranych przedmiotów takie przekształcenia, aby sprawić, że przekształcenia te połączą się w wytwarzaniu nowego przedmiotu, który - w miarę jak jest wytwarzany - zajmuje miejsce w zestawie wybranych przedmiotów jako część tej samej sfery rzeczywistości. Jednak nie zakłada to jeszcze istnienia świadomego celu; to znaczy kreślenia z góry przedmiotu, który ma właśnie być wytworzony"12. Zamierzenie (zamiar) należy zatem odróżnić od celu, który pojawia się dopiero jako efekt ludzkiej czynności. Cel zatem zawarty jest w przedmiocie, w ludzkim wytworze jako efekt czynności decydujący o jego znaczeniu.

Realizacja własnych zamierzeń polega zatem na właściwym rozpoznaniu treści przedmiotu i doborze właściwych narzędzi. Narzędzie jako pośrednik między zamiarem (myślą) a rzeczywistością narzuca ograniczenia wykonywanym czynnościom. Ustala możliwą do urzeczywistnienia treść nowego przedmiotu

\footnotetext{
${ }^{10}$ Tamże, s. 21, przypis 2.

11 ,,Podmiot] wybierając przedmioty swej czynności, wartościuje je zgodnie z określonym wzorcem, i przewidując swe dalsze działania, rozważa je pod kątem określonej normy. Te sądy wartościujące i normatywne stają się dynamicznymi częściami jego czynności, albowiem jedne i drugie warunkują kształtowanie się jej zamiaru. A kiedy zamiar jest ukształtowany, czynność postępuje ku jego realizacji”. F. ZNANIECKI, Rzeczywistość kulturowa, tłum. J. Wocial, w: TEGOŻ, Pisma filozoficzne, t. 2, Warszawa: Wydawnictwo Naukowe PWN 1991, s. 507-508.

12 Tamże, s. 679.
} 
oraz określa podstawę nowego znaczenia. Ogniwem łączącym treść i znaczenie przedmiotu jest system sytuacji określający schemat przebiegu czynności. System ten obejmuje wszelkie sytuacje pomocnicze, które są konieczne, aby zrealizować sytuację modelową (schematyczną) dla danych czynności - tak, aby za pomocą odpowiednich narzędzi urzeczywistnić zamierzony cel ${ }^{13}$. Czynności nie są zatem zdeterminowane na sposób zewnętrzny (jak Durkheimowskie fakty społeczne ${ }^{14}$ ) ani nie podlegają podporządkowaniu celom (klasyczne podejście teleologiczne w filozofii praktycznej Arystotelesa ${ }^{15}$ ). Czynności określone są przez zamiar, który - jeśli jest płynny i stale modyfikowany - nadaje czynnościom walor twórczy, jeśli jest stały i określony to walor odtwórczy. Służą one zatem albo do podtrzymywania systemu społeczno-kulturowego (reorganizacja zachowawcza), albo do jego twórczego udoskonalania ${ }^{16}$.

Punkt wyjścia w pojmowaniu czynności jest u obu polskich myślicieli odmienny. Twardowski proponuje analityczne rozważania oparte na semiotyce języka polskiego. Dokonując subtelnych rozgraniczeń, wskazuje na autonomię wytworów ludzkich, które stają się podstawą odkrywania natury czynności - twórczości, jako efektu gry wyobraźni, oraz odtwarzania, jako efektu posługiwania się danymi pamięci. Dlatego mówiąc o zamierzeniach, wskazuje na sposoby użycia wytworów jako znaków, ale ich faktyczne znaczenie proponuje odnajdywać w treściach wytworów. Znaniecki, analizując czynności, widzi ich powiązanie z realizacją konkretnych sądów wartościujących i normatywnych. Podkreśla autonomię czynności, o której decyduje zamiar podmiotu, jako możliwość realizacji określonego celu w danych sytuacjach. Zamiar ten nie ma charakteru stanu psychicznego, ale jest zdolnością posługiwania się wzorcami kulturowymi przez podmioty działające.

\footnotetext{
${ }^{13}$ Tamże, s. 728.

${ }^{14}$ E. DuRKheIM, Zasady metody socjologicznej, tłum. J. Szacki, Warszawa: Wydawnictwo Naukowe PWN 2000, s. 42.

${ }^{15}$ Filozofia praktyczna Arystotelesa dotyczy namysłu nad celami osiągalnymi i nieosiągalnymi dla dobrego i skutecznego działania. „Bo jak sztuka lekarska wytyka sobie nieosiągalny cel powszechnego ugruntowania zdrowia (a tak samo każda sztuka zmierza do jakiegoś celu bez kresu i pragnie go, w marę możności, osiągnąć, nie przyjmuje zaś za kres swój zdobycia środków do celu wiodących, we wszystkich bowiem kresem jest cel wytknięty), tak i przy zdobywaniu pieniędzy cel jest bezkresny, a jest nim takie właśnie bogactwo i posiadanie pieniędzy". ARYsTOTELES, Polityka, tłum. L. Piotrowicz, Warszawa: Wydawnictwo Naukowe PWN 2006, ks. I, 3, 17.

${ }^{16}$ F. ZnANIECKI, Nauki o kulturze. Narodziny i rozwój, tłum. J. Szacki, Warszawa: Wydawnictwo Naukowe PWN 1971, s. 604-629. Współcześnie M. Archer w tym duchu mówi o morfogenezie zmian społecznych. Structure, Agency and the Internal Conversation, Cambridge: Cambridge University Press 2003.
} 


\section{EFEKTY CZYNNOŚCI LUDZKICH}

Twardowski, zajmując się naturą wytworów psychofizycznych (w tym artefaktów kulturowych), odkrywa naturę czynności, które stały u jej podstaw. Wytwory psychofizyczne mogą, w jego ujęciu, wyrażać wytwory psychiczne. Te drugie wytwory i odpowiadające im czynności psychiczne mogą zatem być wyrażone przez pierwsze, co oznacza, że te same wytwory powodują u odbiorcy te same czynności psychiczne, co u wytwórcy ${ }^{17}$. Jest to jednak inny proces niż wyrażanie przez wytwory psychofizyczne wytworów psychicznych, czyli że wytwory psychofizyczne są wyrazem wytworów psychicznych. „Należy zatem ściśle odróżnić zwrot »wytwór psychofizyczny (podmiot) wyraża wytwór psychiczny (przedmiot)« od następujących między sobą synonimicznych zwrotów: »wytwór psychiczny wyraża się, czyli znajduje swój wyraz w wytworze psychofizycznym «, »wytwór psychofizyczny je s t w y r a z e m wytworu psychicznego«. Rozróżnienie to pozwala usunąć różne nieporozumienia. I tak np. może się ono przyczynić do wyjaśnienia tak bardzo spornej kwestii stosunku muzyki do uczuć. Jeżeli się bowiem wszyscy godzą na to, że w utworze muzycznym mogą się wyrażać uczucia (a także myśli), których doznaje kompozytor, utwór ten, tworząc, nie wynika z tego bynajmniej, by utwór ten owe uczucia wyrażał"18. Utwór muzyczny, podobnie jak każdy wytwór psychofizyczny, jest w tym ujęciu znakiem wytworu psychicznego, który jest z kolei znaczeniem wytworu psychofizycznego. Wytwór psychofizyczny może być natomiast traktowany jako przyczyna podobnych przynajmniej wytworów psychicznych, których jest znakiem $^{19}$. Oznacza to, że wytwór psychiczny istnieje potencjalnie w wytworze psychofizycznym, jest $\mathrm{w}$ nim utrwalony, przez co przybiera pozory wytworu trwałego.

Według Znanieckiego czynności obiektywizują zjawiska społeczno-kulturowe jako dziejące się w ramach zastanego systemu obowiązujących znaczeń, czyniąc je wartościami. Dlatego można ujmować czynności jako ograniczone i dynamiczne

17 „Wytwory psychiczne, które wyrażają jakieś wytwory psychiczne, nazywają się z n a k a m i tych wytworów psychicznych, a same te wytwory psychiczne ich z n a c z e n i e m. Znaczeniem jest tedy każdy wytwór psychiczny, który pozostaje do wytworu psychofizycznego w tym stosunku, że go wytwór psychofizyczny wyraża. Mówimy tedy o znaczeniu krzyku, znaczeniu rysunku, znaczeniu ruchu, znaczeniu rumieńca". K. TwARDOWSKI, O czynnościach $i$ wytworach, s. 21.

${ }^{18}$ Tamże, s. 20, przypis 3.

${ }^{19}$ „Otóż podobnie, jak o przyczynie mówimy, że »istnieje« dalej w skutku, tak też mówimy o skutku, że istnieje potencjalnie już w przyczynie chociażby częściowej. Mówimy więc także, że wytwór psychiczny, będący znaczeniem odpowiedniego wytworu psychofizycznego, czyli odpowiedniego znaku, istnieje potencjalnie w owym wytworze psychofizycznym, w owym znaku". Tamże, s. 23. 
systemy współzależnych, zmiennych wartości ${ }^{20}$. Powstaje w ten sposób ład aksjonormatywny, którego elementem są dyrektywy wykonywania czynności. Dyrektywy te dzięki twórczemu charakterowi czynności ulegają przekształcaniu, organizując doświadczaną rzeczywistość niezależną od człowieka, zgodnie z logiką ludzkich potrzeb ${ }^{21}$. Autor Social Actions rozwija koncepcję czynności jako czynności społecznych, badając je tak, jak się wydarzają, bez szukania dla nich przyczyn psychologicznych w popędach, potrzebach czy impulsach. Czynności społeczne stanowią dla niego odrębny sektor ludzkiej aktywności jako połączenie w system przedmiotu, narzędzia, metody i reakcji. System ten kierowany jest świadomie i bezpośrednio na drugiego człowieka, aby wywołać modyfikację w ramach określonej definicji sytuacji ${ }^{22}$. Czynności społeczne poprzedzone są „elementarnym zainteresowaniem społecznym”, właściwym wszystkim ludzi bez względu na poziom cywilizacyjny i cechy kulturowe. Chodzi o zainteresowania powstałe $\mathrm{w}$ toku ewolucyjnego zaspakajania przez ludzi własnych potrzeb, co powoduje najróżniejsze kontakty społeczne. Takie ujęcie pozwala Znanieckiemu wskazać na elementarne wartości związane z potrzebami i wynikające z tego kontakty, a zarazem uniknąć pytań o fundamenty psychologiczne i motywacje czynności społecznych. Skupia się natomiast na wartościach, które pozwalają podmiotom czynności zdefiniować przedmiot oddziaływania jako istotę świadomą lub służą wywołaniu w tym przedmiocie świadomej reakcji.

Różnica w podejściach do czynności i ich efektów w ujęciu omawianych myślicieli wydaje się na pozór różnicą pomiędzy podejściem źródłowym i obiektywnym $^{23}$. Rozróżnienie to sfomułował Karl R. Popper, uznając, że to pierwsze skupia się na poszukiwaniu genezy danych wytworów (uwarunkowanej światem 2 - ,światem duchowym lub światem stanów umysłowych”), a drugie na określaniu ich logiki wewnętrznej (uwarunkowanej światem 3 -,,światem intelligibiliów lub idei w obiektywnym sensie, jest to świat możliwych przedmiotów myśli: świat teorii samych w sobie, ich relacji logicznych, argumentów i sytuacji problemowych

\footnotetext{
${ }^{20}$ F. ZNANIECKI, Nauki o kulturze, s. 332-333.

21 „Indywiduum tworzy moralność i siebie w niej, jako osobowość moralną, ale tworzy na podstawie moralności danej. Twórczość byłaby absolutną, a jedność moralności i podmiotu moralnego bezwzględnie osiągnięta wtedy, gdyby indywiduum występowało jako twórca ideałów nowych tj. nowych typów tworzenia norm”. F. ZNANIECKI, Formy i zasady twórczości moralnej, „Przegląd Filozoficzny" 1914, z. 1, s. 32.

${ }^{22}$ Z. BOKSZAŃSKI, Koncepcja czynności spotecznych Floriana Znanieckiego na tle niektórych pojęć nurtu teorii działania, „Przegląd Socjologiczny” 1996, nr 20, s. 111-112.

${ }^{23}$ Zob. A. JABŁOŃSKI, Budowanie społeczeństwa wiedzy. Zarys teorii spotecznej Karla R. Poppera, Lublin: Wydawnictwo KUL 2006.
} 
samych w sobie") ${ }^{24}$. Jak jednak zauważyła Antonina Kłoskowska, która rozumie świat 3 jako świat kultury symbolicznej ${ }^{25}$, zastanawiające jest, dlaczego do świata tego oprócz problemów, teorii, mitów, hipotez zalicza Popper także narzędzia czy księgozbiory. Według niej Popper popada w trudności w określeniu zależności między różnymi elementami kultury bytu, kultury społecznej i kultury materialnej ${ }^{26}$. Autorka traktuje to jako przypadek braku staranności w semiotycznych rozstrzygnięciach autora Wiedzy obiektywnej. Według niej, gdyby zastosował konsekwentne rozróżnienie znaków, przekazów i znaczeń, uniknąłby pomylenia substancji znaków (np. książek, bibliotek) ze znaczeniami, czyli funkcjami wynikłymi z relacji między przedmiotami odbieranymi jako znaki a produkującym te znaki i interpretującym je umysłem ${ }^{27}$. Kłoskowska zwraca uwagę na brak zainteresowania Poppera semiotyką, który jej zdaniem jest niezrozumiały w kontekście jego teorii trzech światów.

Koncepcja trzech światów porównywana jest w polskiej socjologii z podejściem Znanieckiego. Treść wytworów czynności ludzkich jest wtedy traktowana jako uwarunkowanie subiektywnych obrazów świata i społecznych postaw ludzi ${ }^{28}$. Świat 3 to zatem tyle, co sposób widzenia treści wytworów człowieka, które dzięki językowi zyskały własny - autonomiczny i realny sposób istnienia. Jest on zależny od człowieka jako jego dzieło, ale może być rozpatrywany jako niezależny od niego punkt widzenia świata. Z kolei Twardowski jasno wskazuje, że z analitycznego punktu widzenia należy zawsze oddzielać wytwory od czynności. Wytwór może być zdaniem Twardowskiego przedmiotem wewnętrznym

\footnotetext{
${ }^{24}$ K.R. POPPER, Wiedza obiektywna. Ewolucyjna teoria epistemologiczna, tłum. A. Chmielewski, Warszawa: Wydawnictwo Naukowe PWN 1992, s. 209; TENŻE, Wiedza a zagadnienie ciata i umystu. W obronie interakcji, tłum. T. Baszniak, Warszawa: Książka i Wiedza 1998, s. 14-20.

25 „Koncepcja świata 3 stawia Poppera wobec problemu, którego komplikacje sam autor sobie uświadamia. S3 (świata 3 - A.J.), obejmuje, zgodnie z jego określeniem, wytwory umysłu ludzkiego, takie jak: teorie naukowe, mity, dzieła sztuki, instytucje społeczne”. A. KŁOSKOwSKA, Socjologia kultury, Warszawa: Wydawnictwo Naukowe PWN 2007, s. 78.

${ }^{26}$ „Szczególne komplikacje w Popperowskim rozumieniu kultury powoduje określenie związku elementów S3, pojętych jako wytwory ludzkiego umysłu (mind), z tym, co Popper nazywa ich ucieleśnieniem, tj. ich fizycznym aspektem, np. książką, substancją rzeźby, obrazu. Treść tego rodzaju elementów kultury Popper oddziela od ich nośnika, który włącza do kategorii Ś1 (świata 1 - A.J.). Oddziela ją także od Ś2 (świata 2 - A.J.), czyli sfery psychicznych doświadczeń ludzi. W rezultacie staje wobec problemu określenia ontologicznego charakteru autonomicznych zjawisk Ś3. Problem ten narzuca się w świetle jego koncepcji niezależnie od tego, czy rozpatrywane elementy Ś3 uznaje on za posiadające ucieleśnienie, czy też wyróżnia wśród nich takie, które jego zdaniem w ogóle nie mają ucieleśnienia (Ś1) ani odpowiednika w sferze procesów psychicznych (Ś2)”. Tamże, s. 78-79.

${ }^{27}$ Tamże, s. 89-90.

${ }^{28}$ M. ZlóєKOwSKI, Wiedza, jednostka, społeczeństwo. Zarys koncepcji socjologii wiedzy, Warszawa: Wydawnictwo Naukowe PWN 1989, s. 169-182.
} 
czynności, tak jak kreska względem czynności kreślenia ${ }^{29}$, albo przedmiotem zewnętrznym, czyli wcześniej istniejącym przed poddaniem go czynnościom ${ }^{30}$. Należy też wyraźnie pokreślić, że wytwór psychiczny nie może być trwały ${ }^{31}$. W sposób widoczny, zewnętrzny czynności psychiczne ujawniają się dopiero w wytworach psychofizycznych.

Dlatego w ujęciu lwowskiego filozofa takie rzeczowniki, jak: „sąd”, „wiara” czy „mowa” oznaczają zarówno wytwór, czynność, jak i dyspozycję. „Jeżeli powiadamy, że mowa czyjaś trwała godzinę, mamy na myśli czynność mówienia, wygłaszania mowy; w zwrocie »mowa twoja niech będzie tak i nie « chodzi o wytwór mówienia, a gdy powiada się, że komuś przerażenie odjęło mowę, chodzi

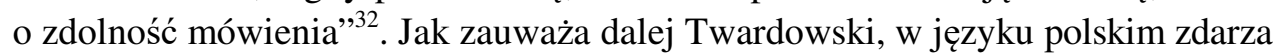
się często, że rzeczownik słowny - wierzenie, mniemanie, zapatrywanie, pragnienie, rozumowanie, żądanie - oznacza zarówno wytwór, jak i czynność czy dyspozycję. Dyspozycje poprzedzają czynności, stanowiąc potencjalne pojęcia, przekonania, pragnienia, które mogą aktualizować się poprzez przyszłe czynności. „Potencjalność tę można pojmować w sposób chociażby najbardziej daleko idący, gdy np. mówi się o »istnieniu « prawd, których jeszcze nikt nie zna, tj. o »istnieniu « prawdziwych sądów, których jeszcze nikt nie wydał. Chodzi tu oczywiście o możność wydania tych sądów a tym, co istnieje, nie są to sądy, lecz jest nim możność ich wydania"33. Jeżeli wieloznaczności te mają w dużej mierze charakter semiotyczny czy też gramatyczny, to rozróżnienie czynności i wytworów jest istotne z punktu widzenia opisu różnych rzeczywistości - moment czynnościowy i moment zjawiskowy/zdarzeniowy.

29 „Przykładami takich czynności i wytworów są: kreślić - kreska, splatać - splot, odciskać - odcisk, rysować - rysunek, pisać - pismo, drukować - druk, malować - malowidło, rzeźbić - rzeźba, budować - budynek itp. Rzeczownik, złączony w każdej parze wyrazów z odpowiednim czasownikiem, może pod względem gramatycznym spełniać względem niego rolę dopełnienia, czyli przedmiotu wewnętrznego". K. TWARDOWSKI, O czynnościach $i$ wytworach, s. 15.

${ }^{30}$ „A ponieważ wytwory trwałe, tak samo jak nietrwałe, są wytworami, tj. czymś, co dopiero dzięki jakiejś czynności powstaje, przeto należy je na równi przeciwstawiać przedmiotom zewnętrznym, tj. czemuś, co już istnieje, zanim przechodząca na nie czynność się rozpoczęła. Dlatego też koordynujemy przedmioty wewnętrzne i zewnętrzne, czyli przedmioty, które są wytworami pewnych czynności, i przedmioty, które nie są wytworami, a przedmioty, które są wytworami dzielimy na dwie współrzędne grupy, na przedmioty nietrwałe i trwałe". Tamże, s. 16.

${ }^{31}$ „Wprawdzie mógłby się ktoś powołać na to, że pewne czynności psychiczne dokonywują się przecież na pewnym »materiale«. I tak, tworząc fantastyczne wyobrażenia, operujemy materiałem wyobrażeń dostarczonym nam przez pamięć; tworząc łańcusznik, układamy w pewien sposób sądy, służące za »materiał « do niego. Ale kto by w ten sposób chciał dowodzić trwałości pewnych przynajmniej wytworów psychicznych, zapomniałby, że musiałby też dowieść, iż owe inne wytwory psychiczne, które odgrywają rolę »materiału« są wytworami trwałymi”. Tamże, s. 18.

${ }^{32}$ Tamże, s. 10.

${ }^{33}$ Tamże, s. 15, przypis 1 . 
Dlatego użycie wynikającego z konkretnej czynności psychicznej wytworu psychofizycznego wywołać może szereg różnych czynności psychicznych, co nie oznacza jednak, że szereg tych czynności tworzy jeden i ten sam wytwór psychiczny. W ten sposób - błędnie zdaniem Twardowskiego - nadaje się wytworom psychicznym charakter czegoś nie tylko trwałego, ale i doniosłego samego w sobie. Dodatkowo różne treści, odkrywane w przedmiotach, których nikt nie uczynił (tzw. niby-wytwory), traktowane są, jak gdyby były wytworami bez czynności, np. rysunek, gdy patrzymy na splot włókien liścia. Twardowski oprócz „niby-wytworów” wskazuje też na wytwory sztuczne albo zastępcze, czyli artefakty, powstałe wskutek czynności odmiennych niż naturalnie uczynione, jak przykładowo odcisk stopy wykonany przez wyżłobienie gliny rękami.

W przypadku wytworów trwałych, takich jak: obrazy, budowle, rzeźby moment zjawiskowy, będący wewnętrznym przedmiotem czynności, staje się - zdaniem Twardowskiego - dzięki przekształceniu materii przedmiotem zewnętrznym, czyli rzeczą. Każdy wytwór psychofizyczny jest efektem nie jednej, lecz kilku czynności psychofizycznych i mogą się w nim wyrażać w sposób bezpośredni i pośredni różne wytwory psychiczne. „Twierdzenie zatem, że w jakimś wytworze psychofizycznym wyraża się jakiś wytwór psychiczny, czyli że jakiś wytwór psychiczny znajduje swój wyraz w wytworze psychofizycznym, sprowadza się do dwóch momentów - po pierwsze, że wytwór psychiczny (wraz z odpowiadającą mu czynnością psychiczną) jest częściową przyczyną powstania wytworu psychofizycznego, a po drugie, że ów wytwór psychiczny, tak jak odpowiadająca mu czynność psychiczna, pod zmysły nie podpada, gdy tymczasem wytwór psychofizyczny pod zmysły podpada"34. Każdy wytwór psychofizyczny wyraża pewne wytwory psychiczne bezpośrednio, a inne w różnych stopniach wyraża w sposób pośrednio. „I tak w rysunku wyrazić się może wyobrażenie rysunku, które rysownik ma, kreśląc rysunek, dalej pojęcie, które rysownik pragnie swym rysunkiem uzmysłowić, pragnienie uzmysłowienia pojęcia itp. ${ }^{, 35}$.

Według Twardowskiego proces utrwalania wytworów nietrwałych w postaci trwałych (np. krzyk nagrany na płycie gramofonowej) wymaga czynności, które same z siebie nie są zdolne tego uczynić. „Czynność koncypowania pewnego układu kresek, czyli wyobrażenia sobie tego układu, więc czynność wytwarzająca wyobrażenie tego układu, sama z siebie nie jest zdolna tego wyobrażenia utrwalić. Trzeba na to czynności odrębnej, mianowicie kreślenia rysunku, więc czynności „technicznej” i dopiero ona wytworzy wytwór trwały, mianowicie pewien układ kresek na papierze, w którym się wyobrażenie

\footnotetext{
${ }^{34}$ Tamże, s. 19.

${ }^{35}$ Tamże, przypis. 2.
} 
rysownika wyrazi”36. Najlepszą techniką utrwalania wytworów psychicznych pozostają znaki językowe.

Twardowski traktuje artefakty jak przedmiot analiz, wychodząc od logiki. Zajmuje się ona sądami, a ściślej powiedzeniami wyrażającymi te sądy, przedstawionymi tylko ${ }^{37}$, które zastępują sądy wydane i powiedzenia rzeczywiste. Logika zajmuje się zatem przedstawieniami sądów, czyli sztucznymi powiedzeniami, których znaczeniem nie są sądy realnie wydane, ale sądy tylko przedstawione, czyli przedstawienia sądów. Sądy przedstawione to rodzaj wytworów zastępczych, które uznać można za skrajny przypadek oderwania wytworów psychicznych od czynności. „Operując takimi wytworami zastępczymi w nauce i w życiu potocznym, nie odczuwamy też żadnej trudności w operowaniu niezastępczymi wytworami, niezależnie od wytwarzających je czynności, tym bardziej, że niezmiernie często wytwory rzeczywiste i zastępcze zjawiają się na przemian, np. gdy wydajemy sąd, który przyjęliśmy zrazu z niedowierzaniem" ${ }^{\text {"38 }}$.

Dla Znanieckiego czynności widziane są jako składowa społeczno-kulturowej osobowości ludzkiej. Analizuje ją jako organizację czynności i wartości przez dominujący w biografii ludzkiej ośrodek integracyjny, system czy wzór społeczno-kulturowy (np. religijny). Jak stwierdza Znaniecki: „Chodzi o to, że większą część naszego życia świadomego spędzamy na schematycznym budowaniu bądź urzeczywistnianiu sytuacji praktycznych narzuconych przez pewne dogmaty; że w naszej refleksji zdroworozsądkowej odnajdujemy się zazwyczaj wśród jakiejś działalności praktycznej i wobec tego nasze obecne doświadczenie przeważnie dąży do jakiejś określonej sytuacji; że ta część naszego przeszłego doświadczenia, jaką obecnie pamiętamy, jawi się w pamięci jako skupiona wokół pewnego schematu; że ta część naszego przyszłego doświadczenia, której obecnie oczekujemy, jawi się w tym oczekiwaniu jako utrwalona i ujednolicona przez pewien dogmat" ${ }^{39}$.

Dogmatyczne przywiązanie do pewnych treści nie oznacza braku twórczego podejścia do rzeczywistości, lecz uwzględnienie zastanych treści kulturowych stanowiących zasób mogący podlegać dalszemu rozwojowi. „Zarówno rozwój

\footnotetext{
${ }^{36}$ Tamże, s. 25.

37 „Sąd jako wytwór czynności sądzenia, czyli wydawania sądów, wyraża się w powiedzeniach, tj. w wytworach psychofizycznych, które powstają dzięki czynności psychofizycznej wypowiadania, czyli wygłaszania powiedzeń. Takie powiedzenia wyrażają tedy sądy, czyli znaczeniem tych powiedzeń są sądy. Można jednak tworzyć powiedzenia sztuczne, zastępcze, które nie będą wyrazem sądów wydanych, lecz wyrazem wytworów sztucznych, zastępujących sądy wydane, mianowicie sądów tylko przedstawionych”. Tamże, s. 29.

${ }^{38}$ Tamże, s. 30.

${ }^{39}$ F. ZNANIECKI, Rzeczywistość kulturowa, s. 767-768.
} 
systemów ideologicznych jako ideałów, jak i utrwalanie ich w postaci dogmatów, zależą od celowych czynności - ściślej mówiąc, społecznych czynności - jednostek i grup, które jawnie dążą do tego, by ludzie zaakceptowali te systemy i podporządkowali się kierownictwu zawartych w nich wzorców wartości i norm postępowania" ${ }^{\text {"40 }}$.

Znaniecki świadomy jest odmienności logiki czynności twórczych i logiki wytworów. Uważa, że przykładowo rozwój nauki tylko osobom niezaangażowanym w tą twórczą czynność jawi się jako „chaotyczne następstwo coraz to odmiennych, a sprzecznych między sobą poglądów”. Jego zdaniem istnieje „związek systematyczny twórczych czynności naukowych o logice wewnętrznej, zupełnie niewspółmiernej z logiką związku symbolicznie ustabilizowanych wytworów tych czynności, choć ta logika nie została jeszcze należycie zbadana” ${ }^{41}$. Logika czynności twórczych jest jego zdaniem czymś jeszcze zupełnie nowym, co wymyka się wyjaśnieniom, ale należy do dynamicznych systemów otwartych tworzących stale nowe czynności. Dlatego wielkie dzieła nauki, sztuki, grupy społeczne, wierzenia i obrzędy trzeba rozpatrywać jako dynamiczną prawidłowość, różną od statycznych struktur rekonstruowanych w gotowych wytworach.

\section{SPECYFIKA NAUK HUMANISTYCZNYCH}

Sposób pojmowania czynności oraz wzajemnych relacji między czynnościami i wytworami wpływa na zaprezentowaną przez obu myślicieli koncepcję nauk humanistycznych. Mimo różnych punktów wyjścia analizowanych polskich myślicieli zbliża antypsychologistyczny sposób rozumienia ludzkich czynności. Takie rozumienie powinno być zdaniem obu badaczy podstawą refleksji humanistycznej ${ }^{42}$. Twardowski, wychodząc od analizy znaczeń związanych z terminami określającymi ludzkie czynności, dochodzi do traktowania znaczeń językowych - wytworów ludzkich czynności - za podstawę namysłu nad indywidualnym i społecznym wymiarem życia ludzkiego. Znaniecki, wychodząc od czynności ludzkich jako zdolności do wyrażenia sądów o treści własnych czynności w ramach określonego systemu kulturowego, czyni z tak rozumianych czynności podstawę

\footnotetext{
${ }^{40}$ TENŻE, Nauki o kulturze, s. 499.

${ }^{41}$ TeNŻE, Ludzie teraźniejsi a cywilizacja przyszłości, Warszawa: Wydawnictwo Naukowe PWN 1974, s. 82.

${ }^{42}$ Mam na myśli szczególnie badania z pogranicza humanistyki i nauk społecznych, jak zarysowana przeze mnie koncepcja socjologicznych badań nad literaturą. A. JABŁOŃSKI, Zarys realistyczno-krytycystycznej koncepcji socjologicznej analizy literatury, „,Roczniki Nauk Społecznych” 9 (45) (2017), nr 4, s. 67-95.
} 
refleksji nad zdolnościami ludzi do urzeczywistnienia możliwości cywilizacyjnych.

Właściwości wytworów zastępczych wskazują, zdaniem Twardowskiego, na możliwość wyodrębnienia przedmiotu nauk humanistycznych, którym byłyby wytwory psychiczne. Wskazuje też na psychologię jako naukę podstawową dla nauk humanistycznych. Musiałaby ona jednak wyraźnie rozróżniać wytwory i czynności psychiczne oraz uwzględniać różne rodzaje wytworów psychicznych. Uważa, że rozróżnienie to „uwalnia logikę od naleciałości psychologicznych”“3. Podobnie może się stać jego zdaniem z innymi naukami humanistycznymi, które nie tylko powinny rozróżniać rodzaje wytworów psychicznych i psychofizycznych oraz uwzględniać relacje między nimi, ale także określać, czy operuje zastępczymi czy rzeczywistymi wytworami psychicznymi. Należy też określić, jak dalece dana nauka ,w rozważaniu wytworów psychicznych abstrahuje od ich cech osobniczych"44. Kolejnym kryterium może być sposób utrwalania wytworów psychicznych w różnego rodzaju wytworach psychofizycznych.

Twardowski, zastanawiając się nad naturą psychologii, odrzuca jej przynależność do klasycznej filozofii i nauk przyrodniczych. Jest to jego zdaniem nauka empiryczna, niezajmująca się ani metafizycznymi kategoriami, takimi jak dusza, ani jedynie biologiczno-fizjologicznymi funkcjami organizmu ${ }^{45}$. Zajmuje się życiem psychicznym, a jej przedmiotem są ,zarówno funkcje, czyli czynności, jak i wytwory psychiczne" 46 . Powiązanie czynności i wytworów składa się na podstawowe fakty psychiczne, które dzieją się w określonych warunkach. Warunki te jako dyspozycje (zdolności, przysposobienia, usposobienia) - postrzeganie, pamięć, wyobraźnia, wola - to hipotetyczne konstrukcje służące powiązaniu i wyjaśnieniu faktów psychicznych. Empirycznie dostępne fakty psychiczne składają się na życie psychiczne zarówno poszczególnych ludzkich indywiduów, jak i całych zbiorowości.

Wyjaśnienia faktów psychicznych, które formułuje psychologia, muszą zatem „[...] na każdym niemal kroku posługiwać się dyspozycjami psychicznymi, jeżeli

\footnotetext{
${ }^{43}$ K. TwardowsKi, O czynnościach $i$ wytworach, s. 31.

${ }^{44}$ Tamże. „Wystarczy przypomnieć sobie, jak różne wytwory psychiczne powstają w różnych osobnikach, na które działa np. ten sam obraz, to samo zdanie. Jak długo jednak mamy ów wytwór psychofizyczny uważać za wytwór, wyrażający jakiś wytwór psychiczny, różność pomiędzy wytworami psychicznymi przezeń wywołanymi, nie śmie iść za daleko, musi istnieć w tych poszczególnych wytworach psychicznych szereg cech wspólnych". Tamże, s. 26.

${ }^{45}$ A. DZIEDZIC, Filozofia wobec psychologii. Polemika Adama Mahrburga z Kazimierzem Twardowskim, „Folia Philosophica” 2017, vol. 38, s. 29-38.

${ }^{46} \mathrm{~K}$. TWARDOWSKI, O psychologii, jej przedmiocie, zadaniach, metodzie, stosunku do innych nauk i o jej rozwoju, w: TEGOż, Wybrane pisma filozoficzne, Warszawa: Wydawnictwo Naukowe PWN 1965, s. 243.
} 
pragnie podać wyczerpujące przyczyny tego wszystkiego, co się w życiu psychicznym dzieje. Stąd też zrozumiałe jest wielkie znaczenie, jakie w psychologii posiadają prawa stwierdzające stałe związki między faktami a dyspozycjami psychicznymi" ${ }^{\text {"47 }}$. Podciąganie faktów psychicznych pod prawa psychologiczne, a te prawa pod prawa ogólniejsze, nie wystarczy w zmierzeniu z sytuacją, zgodnie z którą „każdy fakt psychiczny dostępny jest tylko świadomości tego osobnika, w którym zachodzi" ${ }^{48}$. Aby zatem nie ugrzęznąć w idiograficznym opisie poszczególnych danych introspekcji pojedynczych czynności i wytworów psychicznych, należy badać je w wytworach psychofizycznych. Gdy są to wytwory nietrwałe, to można je określić oznakami życia psychicznego, a gdy trwałe to dokumentami życia społecznego (dokumentami psychologicznymi). „Z wszystkich tych oznak i dokumentów czerpie psycholog pośrednio znajomość cudzego życia psychicznego, niedostępnego introspekcji" ${ }^{49}$. Jeżeli można uznać, że introspekcja jest zdaniem Twardowskiego podstawową metodą psychologii, to tylko jako samospostrzeganie ${ }^{50}$, a nie autoobserwacja ${ }^{51}$. Introspekcja jest zatem konieczna w psychologii, ale niewystarczająca z naukowego punktu widzenia. Może być uzupełniana eksperymentem, czyli introspekcją sztucznie wywołaną, ale musi być uzupełniona metodą przedmiotową, czyli obserwacją faktów psychicznych w oznakach i wytworach psychofizycznych.

Różnica między psychologią a naukami humanistycznymi polega na tym, że ta pierwsza traktuje oznaki i wytwory psychofizyczne jako ściśle powiązane z czynnościami psychicznymi. Natomiast nauki humanistyczne traktują wytwory psychiczne w oderwaniu od czynności psychicznych, ale w odróżnieniu od nauk przyrodniczych traktują wytwory psychofizyczne jako wyraz wytworów psychicznych $^{52}$. Nauki humanistyczne traktują więc psychologię jako naukę pomocniczą, która pozwala zrozumieć genezę badanych wytworów. „Zarówno

${ }^{47}$ Tamże, s. 254.

48 Tamże, s. 258.

${ }^{49}$ Tamże, s. 259.

50 „O faktach, danych nam w doświadczeniu, mówimy wtedy, gdy nam są w doświadczeniu dane, że je s p o s t r z e g a m y, z a u w a ż a m y (appercevior, remarquer, wahrnehmen, bemerken)". Tamże, s. 260.

${ }^{51}$ „Gdy chodzi o dokładne i wszechstronne poznanie jakiegoś faktu, nie można się zadowalać jego dorywczym jedno- lub dwurazowym spostrzeżeniem, lecz należy systematycznie dokonywać kolejno tylu spostrzeżeń, ilu trzeba, aby zauważyć każdą fazę i każdy szczegół faktu. Taki szereg systematycznie, ze skupioną uwagą kolejno dokonywanych spostrzeżeń, celem dokładnego zdania sobie sprawy z następujących po sobie faz zjawiska lub faktu i z jego właściwości, nazywa się o b s e r w a c j ą (observation, Beobachtung). Tamże.

${ }^{52}$ Zob. M. REMBIERZ, Wychowanie, oświata powszechna i ksztatcenie uniwersyteckie jako źródta polskiej niepodległości. Pedagogiczno-patriotyczne idee i działania Kazimierza Twardowskiego, „Polska Myśl Pedagogiczna” 2015, nr 1, s. 39-87. 
więc historyk w najszerszym tego słowa znaczeniu, jak lingwista, jak krytyk literacki itp., dalej socjolog, prawnik, polityk opiera się w swych badaniach na psychologii, gdyż nie może pomijać »psychologicznego« wyjaśnienia przedmiotów, którymi się zajmuje. W miarę jak w badaniach swych zbliża się do genezy wytworów psychicznych i psychofizycznych, które rozpatruje, w miarę więc jak musi cofać się do samego konkretnego życia psychicznego, które owym wytworom dało początek, badanie jego przybiera coraz wyraźniej zabarwienie psychologiczne; w miarę zaś jak się w swych badaniach oddala od kwestii genezy wytworów i rozpatruje już tylko właściwości i stosunki samych wytworów, badania jego przybierają charakter od badań psychologicznych różny i tworzą właśnie jedną z nauk humanistycznych. Badając np. mowę ludzką albo się uprawia psychologię mowy, albo lingwistykę; badając formy, które sobie wytworzyło wspólne życie ludzi, albo uprawia się pewne gałęzie psychologii zbiorowej, albo socjologię itp." ${ }^{, 53}$. Według Twardowskiego zależność ta jest jednak obustronna, dlatego psychologia musi korzystać z ustaleń dotyczących przedmiotów psychofizycznych, zwłaszcza wtedy, gdy - jak w przypadku psychologii zbiorowej - zawodzą techniki introspekcji.

Do koncepcji Twardowskiego nawiązał T. Tomaszewski, który po latach analiz wypracował psychologiczną teorię czynności wyższych. W swej wersji ostatecznej oparta ona była na szerokim rozumieniu rzeczywistości ,,...] w sposób obejmujący przedmioty, ludzi, a także sam podmiot działania (np. ucząc się człowiek stawia przed sobą zadanie przekształcenia samego siebie). Zadanie określa sposób reagowania na bodźce, podporządkowując sobie łańcuchy S-R, które się nań składają. Ostateczna formuła wygląda więc następująco: Z(S-R)W, gdzie $\mathrm{Z}$ oznacza zadanie, czyli cel w jego wyjściowym sformułowaniu, S-R - ciąg odpowiedzi na sytuację bodźcową, W zaś wynik, który może różnić się od założonego celu. Według tej formuły czynność jest zachowaniem celowym, którego punktem wyjścia jest określona sytuacja (stan rzeczy) i które zmierza do osiągnięcia innej określonej sytuacji" ${ }^{54}$.

Według Znanieckiego o specyfice badań humanistycznych, które mają charakter obiektywny, decyduje oparcie je na współczynniku humanistycznym ${ }^{55}$. Obiektywne

\footnotetext{
${ }^{53}$ K. TWARDOWSKI, O psychologii i jej przedmiocie, s. 269-270.

${ }^{54}$ M. MATERSKA, Teoria czynności Tadeusza Tomaszewskiego, w: Psychologia czynności. Nowe perspektywy, red. I. Kurcz, D. Kądzielawa, Warszawa: Wydawnictwo Naukowe Scholar 2002, s. 16.

${ }^{55}$ Ciekawie znaczenie „współczynnika humanistycznego” przedstawia E. Hałas: „Zarówno polska etymologia terminu »współczynnik «, wywodzącego się ze słów »wespół «i »czynić«, jak i łacińska etymologia jego odpowiednika angielskiego coefficient - »co« i efficio - »razem stworzyć«, »zbudować«, »zdziałać«, wskazuje, że termin ten jest związany z pojęciem kolektywnego tworzenia rzeczywistości”. E. HaŁAs, Znaczenia $i$ wartości spoteczne, s. 17.
} 
badanie czynności ludzkich i związków zachodzącymi między nimi pozwalają wyjść poza szukanie uniwersalnych wzorców wartościowania. Znaniecki uznaje zatem, że wszystkie czynności są tej samej natury ontologicznej i powiązane są z zainteresowaniem, czyli specyficznymi tendencjami ukierunkowującymi realizację określonych wartości. Skupia się natomiast na definicji sytuacji, która jest rodzajem konkretnego autorefleksyjnego opisu podmiotu wykonującego dane czynności. Opis ten zawiera elementy zastanawiania się post factum nad danymi czynnościami, porównywania alternatywnych form działania, rozważania wartości, które chce podmiot realizować - ,połączenie wartości z tkwiącymi w ich związkach możliwościami, które można aktualizować lub zapobiegać ich aktualizacji, stanowi właśnie sytuację, jaką zaczyna widzieć wykonawca czynności pod koniec swej refleksji ${ }^{, 56}$.

Definicja sytuacji może dotyczyć czynności teraźniejszych, ale także przeszłych i przyszłych, a nawet wykonywanych przez inne podmioty. Jest to możliwe, gdyż definicje sytuacji przekształcają się w określony wzorzec wartości i normę postępowania, co Znaniecki nazywa ,,[...] modelem postaw lub dokładniej ideologicznym modelem postaw. Jest to model w tym znaczeniu, że ma służyć za doskonały przykład słusznego myślenia o sytuacji, jakiej dotyczy. Od antropologów kulturowych zapożyczamy termin wzór czynności lub dokładniej realny wzór czynności na określenie swoistego ładu wewnętrznego, wynikającego z praktycznego zastosowania wzorców i norm, który sprawia, iż pewne czynności są podobne lub różne od innych czynności" ${ }^{, 57}$.

J. Chałasiński w słowie wprowadzającym ${ }^{58}$ do polskiej edycji Chłopa polskiego w Europie i Ameryce podkreśla równoczesne uwzględnienie w metodologicznym podejściu Znanieckiego zarówno obiektywnej, jak i subiektywnej strony działania społecznego. Z jednej strony uwzględnia sytuację społeczną, a z drugiej postawy, co miało stanowić podstawę nomotetycznej socjologii, która rozpatruje zjawiska społeczne ,jako rezultat nieustannego oddziaływania świadomości jednostki i obiektywnej rzeczywistości społecznej" ${ }^{59}$. Badanie zjawisk społeczno-kulturowych wymaga zatem uwzględniania czynności ludzkich, co należy odróżnić od podejścia introspekcyjnej psychologii, ale i nauk przyrodniczych ${ }^{60}$. ,Jeżeli więc chcemy poznać to, co jest naukowo wytłumaczalne

\footnotetext{
${ }^{56}$ F. ZNANIECKI, Nauki o kulturze, s. 421.

${ }^{57}$ Tamże, s. 465.

58 J. ChaŁAsiński, Polonia amerykańska, w: W.I. ThOMAs, F. ZnANIECKI, Chłop polski w Europie i Ameryce, t. 1, Warszawa: Ludowa Spółdzielnia Wydawnicza 1976, s. 21.

${ }^{59}$ W.I. Thomas, F. ZnANIECKI, Chłop polski w Europie i Ameryce, t. 2, s. 7.

${ }^{60}$ „Badacz kultury, w przeciwieństwie do uczonego przyrodnika [...], stara się odkryć jakiś ład wśród faktów empirycznych, które zależą od tych czynników, są przez nich stwarzane i utrzymywane.
} 
w ludziach jako osobowościach społecznych, musimy naprzód zanalizować porównawczo te wzory kulturalne, według których osobnik organizuje swe różnorodne doświadczenia i czynności społeczne, później zaś rozpatrzyć dynamiczny związek między nimi w ciągu jego życia [...]. Pamiętać jednak zawsze musimy, że tylko w analizie porównawczej oderwanych wzorów osobowych i wydzielonych dążności osobotwórczych możliwe są ścisłe uogólnienia naukowe, gdyż tam różnice indywidualne pominąć można. Wszelkie natomiast uogólnienia, dotyczące kierunku ewolucji osobowości społecznych, uwydatniającego się w całkowitych ich biografiach, mają tylko charakter mniej lub więcej dokładnych wytycznych dla orientacji przybliżonej w różnorodności osobników ludzkich"61.

Wielkie znaczenie dla charakteru prowadzonych przez Znanieckiego badań miało przyjęcie zasady współczynnika humanistycznego, zgodnie z którą zjawiska społeczne mogą zostać rozpoznane jedynie wówczas, gdy poznamy ich obiektywną treść oraz znaczenie przypisywane im w danym momencie przez doświadczających ich ludzi. Fundamentalne założenie badacza brzmiało zatem: „Przyczyną społecznego czy indywidualnego zjawiska nigdy nie jest inne społeczne czy indywidualne zjawisko, ale zawsze połączenie jednego i drugiego"62. Znaniecki we Wstępie do socjologii podał podstawowe sformułowanie współczynnika humanistycznego. Uznał on zjawiska humanistyczne jako przedmioty doświadczeń i czynności obecne zarówno w grupach społecznych najbliższych, jak i dalszych, teraźniejszych, jak i przeszłych. „Sfera, w której obraca się humanista, to nie świat realności samoistnych, jakby się przedstawiał jakiemuś idealnemu, absolutnemu podmiotowi; to świat cudzych »świadomości«, ściślej mówiąc, świat przedmiotów, danych innym konkretnym, historycznie uwarunkowanym, osobnikom i grupom, oraz czynności dokonywanych nad owymi przedmiotami przez tych, którym one są dane jako ich doświadczenia"63. Humanista teoretyk, dążąc do obiektywności swoich ustaleń, musi uwzględnić, że przedmioty jego badań są już dane w doświadczeniu czy w świadomych czynnościach innych. Próba traktowania ich w oderwaniu od tych doświadczeń i czynności, jako przedmioty podobne do tych ujmowanych w naukach przyrodniczych,

Aby wypełnić to zadanie, ujmuje on każdy badany przez siebie fakt empiryczny, z tym co nazwaliśmy współczynnikiem humanistycznym, tj. tak, jak fakt ten jawi się jednostkom ludzkim, które go doświadczali i używają". F. ZnANIECKI, Nauki o kulturze, s. 465-468.

${ }^{61}$ Tenże, Ludzie teraźniejsi a cywilizacja przyszłości, s. 117-118.

${ }^{62}$ W.I. Thomas, F. ZnANiecki, Chłop polski w Europie i Ameryce, t. 1, s. 69. „W sprecyzowanym sformułowaniu: „Przyczyną wartości czy postawy nigdy nie jest sama postawa czy sama wartość, ale zawsze połączenie postawy i wartości”. Tamże.

${ }^{63}$ F. ZNANIECKI, Wstęp do socjologii, Warszawa: Wydawnictwo Naukowe PWN 1988, s. 33. 
nie tylko nie przyczynia się do obiektywności nauk humanistycznych, ale jest jej zaprzeczeniem. Konieczne jest zatem takie traktowanie faktów empirycznych, aby były one ujmowane z tym, co Znaniecki nazywa „współczynnikiem humanistycznym, tj. tak, jak fakt ten jawi się jednostkom ludzkim, które go doświadczali i używają"64.

Takie podejście teoretyczne do zadań nauk humanistycznych wiąże Znaniecki z jej praktycznymi wyzwaniami. Mają one służyć takiemu rozumieniu świata, który pozwoli służyć rozwojowi cywilizacji przyszłości. „Niewątpliwie podstawy, jakie wiedza humanistyczna dać dzisiaj może dla poczynań praktycznych, będą bardzo niedoskonałe naukowo, ale nie możemy czekać na ich udoskonalenie w obecnym okresie przełomowym. Każda zaś próba zastosowania wiedzy jest eksperymentem, przyczyniającym się do jej udoskonalenia i rozbudowy. Dzieje medycyny są tu uderzającym przykładem. A choć mało jeszcze wiemy naukowo o siłach kulturalnych działających w dzisiejszych cywilizacjach, wiemy stosunkowo dużo więcej, niż wiedzieli lekarze greccy o procesach zachodzących w organizmie ludzkim"65. Zestawienie nauk humanistycznych z naukami medycznymi pozwala wyjść z pułapki nazbyt geometrycznego, fizykalnego czy psychologistycznego podejścia do zadań humanistyki. Naukowy charakter refleksji humanistycznej wymaga nie tylko zgodnie $\mathrm{z}$ zaleceniem R. Mertona skupienia się teoriach średniego zasięgu, ale przede wszystkim uwzględnienia związku nauki z poszukiwaniem rozwiązań problemów, które prowadzi do odkrywania nowych problemów.

\section{PODSUMOWANIE}

W podejściu twórcy filozoficznej szkoły lwowsko-warszawskiej mamy do czynienia z próbą obiektywnego spojrzenia na czynności jako sytuacje logiczno-semiotyczne zawarte w ludzkich wytworach. Jest to tworzenie perspektywy służącej do określania ludzkich zachowań w różnych sferach życia - od psychicznego po kulturowo-społeczne. Logiczno-semantyczna analiza wytworów jako efektu czynności daje podstawy naukowego ich traktowania, z zaznaczeniem, że zewnętrzne powody zaistnienia danych zjawisk analitycznie odróżniają się od ukrytych, deterministycznych zależności przyczynowo-skutkowych, właściwych dla zjawisk przyrodniczych. W podejściu autora Chłopa polskiego... czynności ludzkie traktowane są jako tworzywo kultury, czyli ładu stosunków

\footnotetext{
${ }^{64}$ Tenże, Nauki o kulturze, s. 468.

${ }^{65}$ Tenże, Ludzie teraźniejsi a cywilizacja przyszłości, s. 98.
} 
pomiędzy wszystkimi uzewnętrznianymi ludzkimi doświadczeniami. W tym ujęciu czynności ludzkie rozumiane antypsychologicznie są odrębną kulturową sferą ludzkiej aktywności określaną przez wartości. Czynności społeczne dziejące się w konkretnych sytuacjach domagają się definiowania przez wykonawców (współczynnik humanistyczny), co staje się podstawą humanistycznego rozumienia, które upodobnia się do przyczynowo-skutkowego myślenia o zjawiskach przyrodniczych.

\section{BIBLIOGRAFIA}

Arystoteles, Polityka, tłum. L. Piotrowicz, Warszawa: Wydawnictwo Naukowe PWN 2006.

ARCHER M., Structure, Agency and the Internal Conversation, Cambridge: Cambridge University Press 2003.

Bobryk J., Twardowski. Teoria działania, Warszawa: Prószyński i S-ka 2001.

BoKSZAŃSKi Z., Koncepcja czynności społecznych Floriana Znanieckiego na tle niektórych pojęć nurtu teorii działania, „Przegląd Socjologiczny” 1996, nr 20, s. 103-118.

BRYKCZYŃSKI P., Kazimierza Twardowskiego koncepcja wytworów czynności, „Filozofia Nauki” 2005, nr 2(50), s. 27-68.

Chąasiński J., Polonia amerykańska, w: W.I. Thomas, F. ZnAniecki, Chłop polski w Europie i Ameryce, t. 1, Warszawa: Ludowa Spółdzielnia Wydawnicza 1976, s. 21.

DOMINIAK Ł.M., O źródłach kreatywności Floriana Znanieckiego, „Filo-Sofija” 2017, nr 39, s. 179-185.

Durkheim E., Zasady metody socjologicznej, Warszawa: Wydawnictwo Naukowe PWN 2000.

DzIEDZIC A., Filozofia wobec psychologii Polemika Adama Mahrburga z Kazimierzem Twardowskim, „Folia Philosophica” 2017, vol. 38, s. 29-38.

HAŁAs E., Znaczenia i wartości społeczne. O socjologii Floriana Znanieckiego, Lublin: Redakcja Wydawnictw KUL 1991.

JABŁOŃSKI A., Budowanie społeczeństwa wiedzy. Zarys teorii społecznej Karla R. Poppera, Lublin: Wydawnictwo KUL 2006.

JABŁOŃSKI A., Zarys realistyczno-krytycystycznej koncepcji socjologicznej analizy literatury, „Roczniki Nauk Społecznych” 9 (45) (2017), nr 4, s. 67-95.

KŁoskowska A., Socjologia kultury, Warszawa: Wydawnictwo Naukowe PWN 2007.

Materska M., Teoria czynności Tadeusza Tomaszewskiego, w: Psychologia czynności. Nowe perspektywy, red. I. Kurcz, D. Kądzielawa, Warszawa: Wydawnictwo Naukowe Scholar, s. 13-19.

Paczkowska-Łagowska E., Psychika i poznanie. Epistemologia Kazimierza Twardowskiego, Warszawa: Wydawnictwo Naukowe PWN 1980.

POPPER K.R., Wiedza a zagadnienie ciała i umysłu. W obronie interakcji, tłum. T. Baszniak, Warszawa: Książka i Wiedza 1998.

POPPER K.R., Wiedza obiektywna. Ewolucyjna teoria epistemologiczna, tłum. A. Chmielewski, Warszawa: Wydawnictwo Naukowe PWN 1992. 
REMBIERZ M., Wychowanie, oświata powszechna i kształcenie uniwersyteckie jako źródła polskiej niepodległości. Pedagogiczno-patriotyczne idee i działania Kazimierza Twardowskiego, „Polska Myśl Pedagogiczna” 2015, nr 1, s. 39-87.

Thomas W.I., ZnANIECKi F., Chłop polski w Europie i Ameryce, t. 1-2: Organizacja grupy pierwotnej, tłum. M. Matelska, Warszawa 1976.

TwARDOWSKI K., O czynnościach i wytworach. Kilka uwag z pogranicza psychologii, gramatyki i logiki, Kraków: Drukarnia Uniwersytetu Jagiellońskiego 1911.

TwARDOwSKI K., O psychologii, jej przedmiocie, zadaniach, metodzie, stosunku do innych nauk i o jej rozwoju, w: TEGOŻ, Wybrane pisma filozoficzne, Warszawa: Wydawnictwo Naukowe PWN 1965.

WolEńSki J., Twardowski Kazimierz, w: Encyklopedia filozofii polskiej, t. 2, Lublin: Polskie Towarzystwo Tomasza z Akwinu 2011.

ZıóŁKOWSKI M., Wiedza, jednostka, społeczeństwo. Zarys koncepcji socjologii wiedzy, Warszawa: Wydawnictwo Naukowe PWN 1989.

ZNANIECKi F., Formy i zasady twórczości moralnej, „Przegląd Filozoficzny” 1914, z. 1, s. 1-32.

ZNANIECKI F., Ludzie teraźniejsi a cywilizacja przyszłości, Warszawa: Wydawnictwo Naukowe PWN 1974.

ZnANIECKi F., Nauki o kulturze. Narodziny i rozwój, tłum. J. Szacki, Warszawa: Wydawnictwo Naukowe PWN 1971.

ZnANIECKI F., Rzeczywistość kulturowa, tłum. J. Wocial, w: Tegoż, Pisma filozoficzne, t. 2, Warszawa: Wydawnictwo Naukowe PWN, s. 459-928.

ZNANIECKI F., Wstęp do socjologii, Warszawa: Wydawnictwo Naukowe PWN 1988.

\author{
CZYNNOŚCI LUDZKIE JAKO OBIEKTYWNY WYMIAR BADAŃ \\ NAUK HUMANISTYCZNYCH. \\ ANALIZA PORÓWNAWCZA KONCEPCJI KAZIMIERZA TWARDOWSKIEGO \\ I FLORIANA ZNANIECKIEGO
}

Streszczenie

Artykuł jest analizą koncepcji czynności ludzkich dwóch wielkich polskich myślicieli - Kazimierza Twardowskiego i Floriana Znanieckiego. Tekst ma charakter analityczno-syntetyczny z pogranicza historii idei i metodologii. Głównym problemem artykułu jest ukazanie, jakie podejście badawcze w naukach społecznych wynika z koncepcji czynności ludzkich Twardowskiego i Znanieckiego. Prezentują oni odmienne sposoby konceptualizacji czynności ludzkich, które uzupełniają się logicznie i wyznaczają dopełniające się obszary opisu zachowań człowieka. Twardowski dąży do obiektywnego opisu czynności ludzkich jako sytuacji logiczno-semiotycznych zawartych w wytworach człowieka. Taka perspektywa oglądu daje podstawy naukowego ich traktowania, różnego od odkrywania ukrytych, deterministycznych zależności przyczynowo-skutkowych, właściwych dla zjawisk przyrodniczych. W podejściu Znanieckiego czynności traktowane są jako tworzywo kultury, czyli ładu stosunków pomiędzy wszystkimi uzewnętrznianymi ludzkimi doświadczeniami. Stanowi to podstawę humanistycznego rozumienia ludzkich zachowań, które upodobnia się do przyczynowo-skutkowego myślenia w naukach przyrodniczych.

Słowa kluczowe: czynność; nauki humanistyczne; antypsychologizm; Kazimierz Twardowski; Florian Znaniecki. 


\title{
HUMAN ACTIVITIES AS AN OBJECTIVE DIMENSION \\ OF HUMANITIES RESEARCH COMPARATIVE ANALYSIS OF THE CONCEPTS OF KAZIMIERZ TWARDOWSKI AND FLORIAN ZNANIECKI
}

\begin{abstract}
Summary
The article is an analysis of the concept of human activities of two great Polish thinkers Kazimierz Twardowski and Florian Znaniecki. The text is analytical and synthetic in nature, bordering on the history of ideas and methodology. The main problem of the article is to show what research approach in humanities results from the concept of human activities by Twardowski and Znaniecki. They present different ways of conceptualizing human activities, which complement each other logically and define complementary areas of description of human behavior. Twardowski strives to objectively describe human activities as logical and semiotic situations contained in human products. Such a perspective provides the basis for a scientific treatment of them, different from discovering hidden deterministic cause-and-effect relationships specific to natural phenomena. In Znaniecki's approach, activities are treated as a material of culture, i.e. an order of relations between all externalized human experiences. This is the basis of a humanistic understanding of human behavior that conforms to cause and effect thinking in the natural sciences.
\end{abstract}

Keywords: activity; Humanities; anti-psychologism; Kazimierz Twardowski; Florian Znaniecki. 